\title{
Stereotyping of the Don Cossacks in the perception of consumers of folklore- ethnographic tourist and socio-cultural products: to the formulation of the problem
}

\author{
Ekaterina Davidova ${ }^{1 *}$, Antonina Petrenko ${ }^{1}$, and Olga Dudkina ${ }^{1}$ \\ ${ }^{1}$ Don State Technical University, Gagarina Sq., 1, Rostov-on-Don, 344000, Russia
}

\begin{abstract}
Ethnic and social stereotypes are an indicative and multifunctional socio-cultural phenomenon that cannot be considered fully studied either in theoretical or in content-practical terms. The paper compares the results of the analysis of current historical, historiographical and cultural scientific works on Don Cossacks, the study of representations of the culture of Don Cossacks in the tourist and socio-cultural spheres in the Rostov Region (24 objects), a pilot survey $(\mathrm{N}=70)$ of respondents for the reconstruction of ideas about Don Cossacks. In the scientific discourse of recent years about Don Cossacks, there is a tendency to discuss the directed formation of the image of the Cossacks by certain social forces.
\end{abstract}

\section{Introduction}

The youth of the revived Cossacks, attempts to find or form their own identity, as well as the inclusion of the Cossacks in the Russian sociocultural context as a political, military, and ethnocultural force poses researchers with the problem of the representation of the Cossacks in the sociocultural space, the perception of the Cossacks by the population of the region and the country as a whole. It is important to understand what stereotypes of the Cossacks have developed or are developing in Russian society, under the influence of what factors, in whose interests, and what consequences this leads to. This is a wide range of issues that require a preliminary study of the problem field, which is what our study is dedicated to.

The purpose of this work is to build a general configuration of the problem field associated with the stereotyping of the Don Cossacks, which is carried out in representative forms of culture included in socio-cultural activities and tourist practices.

In this article is faced with the following tasks in this regard:

Based on the materials of historical and historical-cultural studies, to identify the prerequisites for the current processes of stereotyping of the Don Cossacks;

\footnotetext{
${ }^{*}$ Corresponding author: katrindavidova@mail.ru
} 
To determine the main features of the Don Cossacks, as it appears in socio-cultural representations;

To analyze the ideas of ordinary people about the Don Cossacks, to isolate the stereotypical component, if any; to determine the role of socio-cultural representations in the formation of the population's ideas about the Don Cossacks.

Before proceeding to the consideration of the problem, will identify the key concepts.

By stereotyping, mean the process of forming a stereotype of an object, that is, a schematic, simplified representation of it with a certain set of stable characteristics, among representatives of a certain community of people. For example, the formation of a stereotype of the Cossacks among consumers of tourist and / or socio-cultural products is the stereotyping of the Cossacks.

Under the socio-cultural product in this article, understand the organization of cultural leisure of people, namely: concerts, excursions, expositions, master classes, fairs, etc. Strictly speaking, the tourist product is one of the types of socio-cultural product. But take it out as a separate object of interest, since separately focus on the tourist offers that exist on the market. Folklore and ethnographic tourist product is organized tourist trips, the main purpose of which is to get acquainted with folklore and immerse yourself in the ethnographic environment of a particular area.

The research is based on the general theoretical principle of consistency. The method is based on the main postulates of the structural-functional approach and functionalism in cultural studies. The object of the study is considered from the standpoint of cognitive cultural studies, which defines stereotypes as cognitive matrices of interpretation, along with style, symbolic systems and, in general, linguistic means.

\section{Methods and materials}

In this article adhere to an extremely broad definition of the key concept: A stereotype is a «simplified, rigid to new information, culturally determined and emotionally colored representation of a fragment of social reality (object, phenomenon, situation) that lives both in the individual consciousness and in the consciousness of entire social groups». A characteristic element of a stereotype is a ready-made assessment of the phenomenon that it reflects. Different researchers use such concepts as image, myth, mythologeme, ideologeme, pattern, representation, etc. as synonymous or close in meaning, revealing, clarifying the meaning of the term, intersecting with it, included in it or including it in themselves.

The preliminary nature of our work makes it necessary to study materials of various types and compare the results obtained. Thus, in the most general sense, the research method consists in comparing the results of studying three subject fields.

Cultural, historical and historiographical studies devoted to the Cossacks and covering the period of its development of about 200 years (from the XIX century to the present day). This component of the study is aimed at identifying the historical and cultural prerequisites for the stereotyping of the Don Cossacks.

Methods of working with the materials of this group: comparative, analytical, generalization method. The main focus was on identifying general trends in the assessment of the image of the Don Cossacks, which are not always obvious when researchers focus on specific historical periods or problems.

The formal representation of the culture of the Don Cossacks in the modern sociocultural space in the field of organized leisure. Creative Cossack collectives operating in the Rostov region, creative and folklore-ethnographic festivals, folk festivals, city holidays, exhibitions and fairs of folk craftsmen, museum expositions, and tourist offers were studied. A total of 24 objects were studied. This component of the study is focused on 
determining the forms and features of the representation of the culture of the Don Cossacks in the cultural and leisure sphere of the region.

When working with this group of materials, used not only methods of collecting information, but also the method of content analysis to determine the main broadcast features of the culture of the Don Cossacks. For this purpose, used photos and video materials posted on the Internet, as well as personal observations of the author. The stated goals of the activity of collectives, clubs, masters, and their correlation with the real content of the activity were studied.

The topic of stereotyping in modern society is actively studied and, accordingly, is widely represented in both domestic and foreign scientific literature. Researchers are currently primarily interested in the influence of ethnic and social stereotypes on various aspects of social and intercultural communication: the question of ethnic disidentification under the influence of ethnic stereotypes [1]; the problem of the ratio of ethnic and cultural diversity [2]; the influence of populist discourses on stereotypes; mapping ethnic stereotypes and identifying factors that determine their nature; difficulties in the methodology of studying ethnic stereotypes [3]. According to these studies, it is stereotypes that have the greatest impact on interethnic communication and identity, rather than real cultural differences.

The issues of stereotyping to which certain objects are subjected in the course of sociocultural activities, in particular-in the course of tourist activities, concert activities, in the process of folklore-ethnographic and historical reconstructions, also fall into the field of scientific interests of modern researchers. Sena da Silveira and Emerson Jose explore tourism as a mechanism for identifying a modern person, in the context of which the subject does not deal with cultural objects, but with their simulacra, which is largely simplified and lacks the depth of the original object [4].

The formation of images in the process of sociocultural activity that do not reflect the essence of the phenomena is also discussed in the study of the history of the Cossack costume by N. Vlaskina [5]. This work is the only work have found that directly addresses the issues of stereotyping of certain aspects of Cossack culture in modern sociocultural activities. However, the topic of the Cossacks in general, and the Don Cossacks in particular, continues to be the subject of sustained research interest for many years.

Research on the Cossacks is concentrated in three areas: history and historiography, cultural studies, and linguistics. The work of E. A. Murashova is of particular interest in the context of our research, which addresses the issues of the correlation between the personal and the stereotypical in the evaluative statements of the Cossack discourse [6], as well as the problems of interpretation of the Cossack discourse by native speakers of the Russian language.

As for the history and historiography, in the works devoted to the history of the Cossacks of the last 200 years, there is an obvious tendency to compare the image of the Cossacks in the public consciousness of the non-Cossack population of Russia with the real Cossacks. The study of publications allowed us to identify three key points in history, which, according to scientists, are the most significant and critical in the formation of the image of the Cossacks in the public consciousness: the second half of the XIX century and the beginning of the XX century, when tsarism sought support and a guarantee of the stability of the regime in the Cossacks (this topic is covered in the works of N. A. Mininkov and L. V. Mininkova, A. Peretyatko, A. M. Ryblova [7-9]; the first two decades of Soviet power, when the Soviet regime was forced to look for ways to integrate the Cossacks into Soviet society (this period is devoted to the works of V. S. Klopikhina, A. S. Pankratov, O. V. Rvacheva [10-12]); the modern stage of the development of the Cossacks, which begins in the 90s of the last century and is associated with the revival and search for the identity of the Cossacks (aspects of historical development associated with this stage are studied in the 
works of G. O. Matsievsky, N. G. Ochirova, Yu.I. Pertseva, A. Popov, O. V. Rvacheva, L.N. Kazmina, Makarenko, V.S., Provotorina, V.V., Shevchenko E.M., Petrenko, A.S [13-20].

The research is based on the general theoretical principle of consistency. The method is based on the main postulates of the structural-functional approach and functionalism in cultural studies. The object of the study is considered from the standpoint of cognitive cultural studies, which defines stereotypes as cognitive matrices of interpretation, along with style, symbolic systems and, in general, linguistic means.

When working with this group of materials, used not only methods of collecting information, but also the method of content analysis to determine the main broadcast features of the culture of the Don Cossacks. For this purpose, used photos and video materials posted on the Internet, as well as personal observations of the author. The stated goals of the activity of collectives, clubs, masters, and their correlation with the real content of the activity were studied.

\section{Results}

The authors of scientific publications on the history of the Cossacks point to attempts to deliberately form a certain image of the Cossacks in different historical periods.

For the XIX century, the ideas of primordial monarchism, patriarchal religiosity and contempt for women in the Cossack environment are characteristic. The study of A. Peretyatko reveals similar stereotypical ideas about their own history and culture that do not correspond to reality among the Don Cossacks of the mid-XIX century [21]. Foreign authors also point to the consistent and purposeful formation of the" imperial center "of the" myth of the special relationship between the tsar and the Cossacks" [22]. The Mininkovs, based on historical evidence, say that at the beginning of the XX century, the idea of the Don Cossacks as conservative, preserving their traditions and way of life since the Middle Ages, took root in non-Cossack territories [23].

«Cossacks» at performances are always dressed in stylized bright festive traditional outfits, and «Cossacks» - in military uniforms. The repertoire of the ensembles includes a wide variety of numbers: lyrical, solemn, festive, ritual content. Ensembles that are engaged not only in musical, but also dance numbers, in the repertoire there are always numbers that imitate the elements of combat or demonstrate the military prowess of the Cossacks.

Ensembles of the Don Cossacks use images of representatives of other Cossacks and even other ethnic groups in their performances. In their work, the ensembles turn not only to traditional works, but also include the author's work in the repertoire.

In the names of ensembles, their numbers, in the content of the numbers and in the descriptions of activities, there are necessarily direct or indirect references to religious topics.

The administration of the region, city, districts of the region and settlements provides support to Cossack ensembles.

Under the festivals of Cossack culture, the organizers usually understand the performances of Cossack ensembles. Sometimes the program is supplemented by theatrical performances and reconstructions of traditional Cossack rites, which take place on the stage, that is, they are also essentially concert numbers.

Festivals held in open areas include additional elements of active leisure for visitors: «ethnic» Cossack games, dances, and Cossack treats. Those who wish are given the opportunity to try themselves in the possession of weapons, much less often-in the reconstruction of simple household activities.

Festivals can be supplemented with competitions of a sporting nature: jigging, flanking. At their core, these festival components are also demonstrative. 
Festivals of Cossack culture are accompanied by «Master Fairs», where souvenirs with recognizable stylized «ethnic» forms are presented.

As a separate type of festival, historical reconstructions can be considered, which also have a demonstrative character, have classified national and city holidays as festivals. The only difference between them is the absence of a competitive component in the holiday program.

The festival activities emphasize the religious discourse (up to the coverage of the opening of the festival) and the military character of the Cossacks. Also striking is the close relationship between the festival organizers and the local authorities.

For comparison, the sample included Cossack festivals held outside the Rostov region and even the Southern Federal District, in which groups working in the traditions of different Cossacks take part. It should be noted that the wider the scope of such events and the higher their level, the more formal they are. At the highest level, only the decorative and demonstration component is preserved.

As a rule, the goals of festivals and activities of Cossack ensembles are the popularization and dissemination of the Cossack heritage and traditions, and the preservation of the historical memory of the people.

The idea of the inhabitants, who are not directly related to the Don Cossacks, about the Don Cossacks and their culture. A pilot study was conducted through a written questionnaire. The study involved 70 people aged 15 to 52 years. 60 of the respondents live in the cities of the Rostov region. 37 people - residents of remote regions of Russia, who were involved in the survey through social networks. The questionnaire included three groups of questions:

- $\quad$ aimed at identifying the respondent's ideas about the Don Cossacks;

- aimed at determining the range of specific knowledge of the respondent about the history, culture and role of the Don Cossacks in the history of the country and the region;

- focused on reflection on the sources of knowledge and the respondent's ideas about the Don Cossacks.

The purpose of the survey was to isolate the stereotypes associated with the Don Cossacks, and the primary determination of their possible sources.

It is necessary to consider as separate groups museums in the traditional sense, representing collections of exhibits within the framework of limited fragmentary reconstructions of interiors or places, and museums organized in historical buildings with the maximum preservation of authentic structure and decoration. Museums of the first group represent a limited set of objects related to a particular culture, paying insufficient attention to their functionality and inclusion in a complex system of everyday life and ritual relations. The museums of the second group give a more accurate idea of ethnic culture, since they reproduce a certain system in its entirety.

However, in both cases, the visitor is dealing with a static exposure. He doesn't see real people interacting with objects - cultural artifacts. Museums provide an opportunity to participate in extremely fragmentary reconstructions of everyday actions or rituals, or to become a spectator of them. But this does not happen all the time and mainly for tourist groups.

Most of the tours involve only visiting museums and historical sites. The most advanced tours include participation in ethnographic reconstructions of rituals, concerts of folklore groups and master classes in traditional crafts, as well as original games related to the imitation of everyday skills of the Cossack life. Some "Cossack" tours include visits to sites that are not directly related to either the old or modern Cossacks.

Fig. 2 shows the distribution of the number of concepts used to describe the views of the Don Cossacks by respondents living in the Rostov region. 


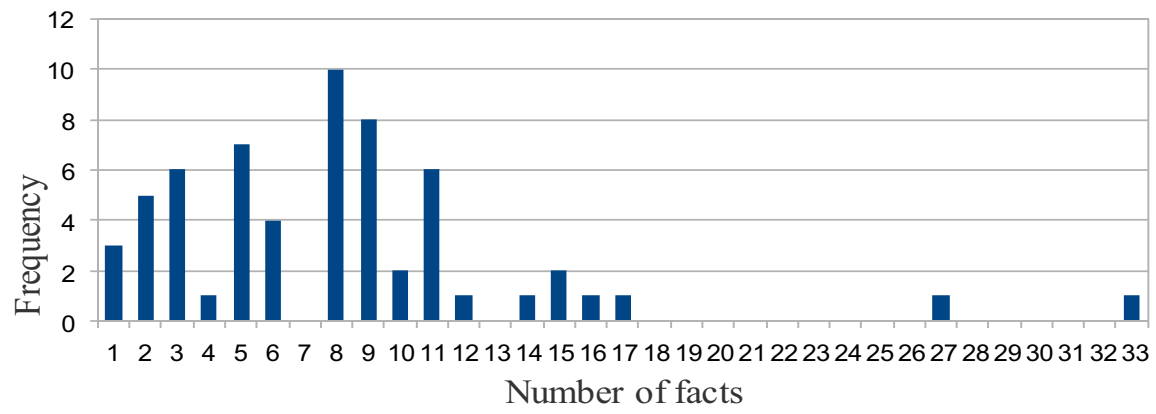

Fig. 1. Distribution of the number of facts mentioned by the residents of RR.

And Fig. 3 shows the frequency of mentions of a particular concept by respondents from the entire sample. The diagram includes the most frequent concepts. In total, there are 34 of them. If the local population's stereotypes were quite broad and had some thematic diversity, then the residents of remote regions have only one association with the Don Cossacks: a man on a horse and with a saber.

Cossacks in the minds of respondents are associated with male images. Women's images, activities, elements of everyday life, etc. were mentioned in the responses of only five respondents.

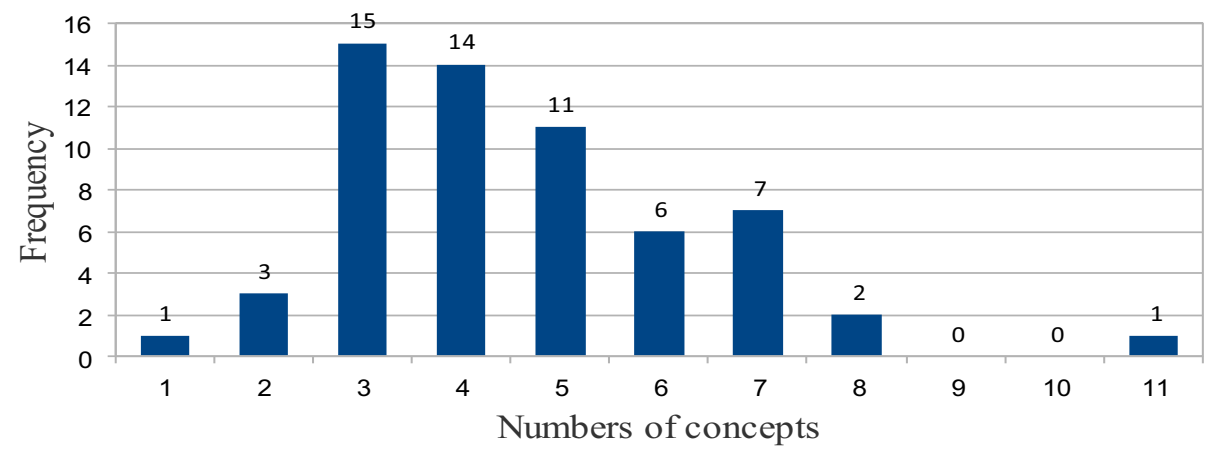

Fig. 2. Distribution of the number of concepts used to describe the Don Cossacks by respondents living in the RR. 

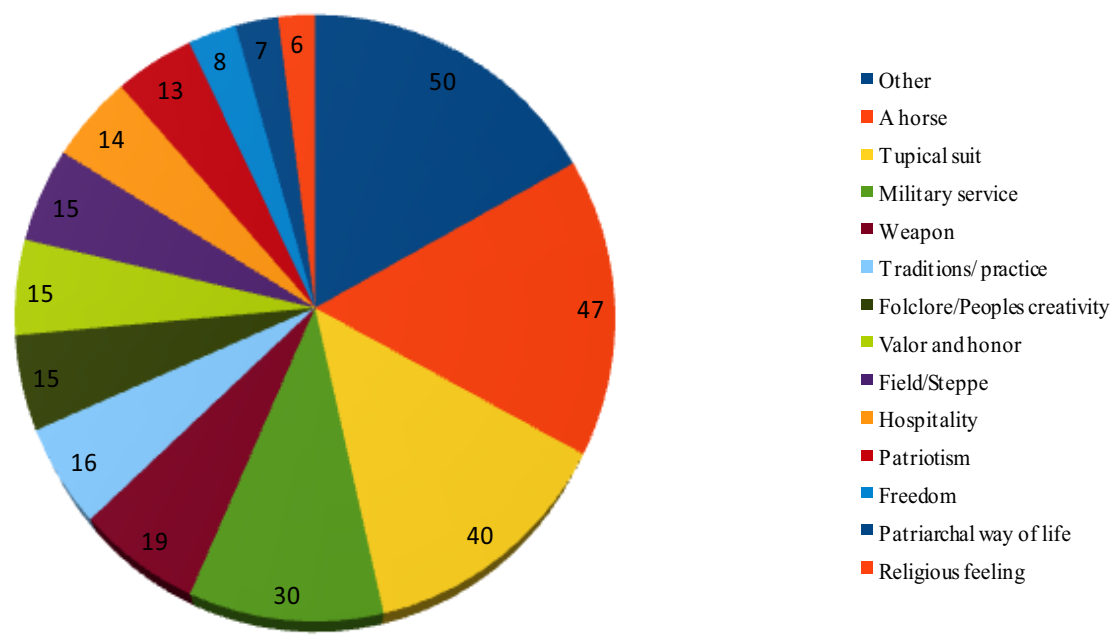

Fig. 3. Frequency of occurrence of some concepts in the questionnaires of the entire sample (70).

Literature and cinema, media materials, museum expositions and excursions to historical Cossack places, historical reconstructions, performances of Cossack amateur groups, souvenirs and works of folk craftsmen were indicated as sources of ideas about the Cossacks.

Among the residents of RR, 17 people indicated that they had communicated with modern Cossacks. Of these, only 5 indicated personal contacts as sources of ideas about the Cossacks.

The residents of RR had their own ideas about the Don Cossacks based on various sources, but none of them mentioned training courses or textbooks. Residents of other regions, on the contrary, were called one single source of ideas about the Cossacks - school history textbooks.

Respondents were asked to rank the sources of knowledge and ideas about the Cossacks by the degree of importance, where 1 is the main source, and then they are arranged in descending order of importance. Table 1 shows the rating of sources of ideas about the Don Cossacks, indicating the number of questionnaires in which they are mentioned.

Table 1. Rating of the source of ideas about the Don Cossacks according to the data of the entire sample (70).

\begin{tabular}{|c|c|c|}
\hline $\begin{array}{c}\text { Position in } \\
\text { the rating }\end{array}$ & Source of knowledge and ideas about the Cossacks & $\begin{array}{c}\text { Number of } \\
\text { mentions }\end{array}$ \\
\hline 1 & Literature and cinema & 43 \\
\hline 2 & $\begin{array}{c}\text { Performances of folklore groups and historical / ethnographic } \\
\text { reconstructions/ souvenirs }\end{array}$ & 38 \\
\hline 3 & Museum exhibitions and excursions & 23 \\
\hline 4 & Media materials & 19 \\
\hline 5 & Training courses / textbooks & 10 \\
\hline 6 & Personal contacts with the Cossacks & 5 \\
\hline
\end{tabular}




\section{Discussion}

The stereotyping of the Cossacks performed certain functions at every historical moment. The Soviet government was forced to look for ways to include the Cossacks in the new Soviet realities. Already in modern Russia, the image of the Cossack is consistently created, justifying the claims of the Cossacks to a special position in society and the state. This idea is partly confirmed by Rvacheva, stating that the restoration of historical truth «actually created a new image of the Cossacks in modern Russia» [21].

The traditional perception of the Cossacks since pre-revolutionary times «as a conservative phenomenon and poorly amenable to modernization and progress» [24] is easily reconstructed in post-Soviet Russia, and the Cossacks are used as a symbol of returning to the traditions of the monarchical past and restoring broken historical ties.

The most disturbing trend is that some publications indicate ([5]), while others present (for example, [25]), to identify the conventionally traditional culture of the Cossacks with Russian culture, or more broadly, with Russian culture as a whole. Russian Cossacks are represented as the bearer of Russian spirituality, the expression of the common interests of the nation, «the expression of the socially significant values of Russian culture» («the expression of the socially significant values of Russian culture») [25].

The specificity of the stereotyping of the Don Cossacks over the past 200 years is that it was carried out intentionally and from above.

The content of the representations of the Don Cossacks in the socio-cultural sphere of the region

In the artistic discourse, the Cossacks appear as an undifferentiated mass. The activity of the largest Cossack ensembles is a mixture of external and essential features of the cultures of different Cossacks. Therefore, it is not surprising that the respondents, even those living on the Don, showed a complete lack of understanding of the peculiarities of the Don Cossacks, confusing it with other Cossack cultures.

The main problem of the representations of the Cossack culture is that the demonstrative forms are still disconnected from everyday life and the living modern Cossack culture.

The everyday side of Cossacs life is represented by museum expositions only with some extend. But are talking about the life of the Cossacks, as it was in the pre-revolutionary era. And to this day, these representations remain static, that is, the tourist, the viewer, the tourist does not show the activity side, but only the subject side.

It can be assumed that this is why in the minds of consumers of socio-cultural and tourist products are fixed:

Festive and concert images of the Don Cossacks;

External, bright attributes that are not correlated with the spiritual and moral foundations of culture, traditional or modern.

Since the socio-cultural and tourist product dedicated to the Cossacks includes numerous elements that are not related to the Cossack culture, the consumer is immersed in a confusion of vivid images. And if he does not have special training and knowledge, then he is deprived of the opportunity to get an adequate idea of the culture of the Don Cossacks.

The fact that, on average, respondents used only 4.6 concepts to describe their ideas about the Cossacks, clearly indicates their simplicity and stereotyping. And the concentration of these concepts in the thematic field of male military culture indicates a certain bias of the sources through which these ideas are formed.

Cossacks in the minds of our contemporaries appear as rural residents with a communal way of life, which is represented today in songs, music and dances, in stylized folk costumes and bast crafts for tourists. And this is despite the fact that for two centuries (XVIII-XIX), the authorities of the Russian Empire purposefully formed the elite and urban 
culture of the Don Cossacks, seeking to ensure the integration of the Cossack elite into the all-Russian cultural tradition [20].

Many of our contemporaries associate the Cossacks with freemen, which is understood as promiscuity and permissiveness. However, historical and cultural studies confirm that the life of the Cossack was comprehensively regulated by legal and moral norms, as well as natural cycles that impose their own requirements on the organization of labor [8].

Active stereotypes are noticeably limited to a certain topic. For example, it was a big surprise that the agricultural nature of the Cossack culture was mentioned much less often than, for example, hunting and fishing as the main activity of the Cossacks. The main connotations are associated with military affairs, demonstrativeness/decorativeness, certain conditional "traditions", as well as a purely positive image of the Cossack-man (patriotism, loyalty, honor, valor, courage, good-neighborliness, hospitality, etc.). They are contrasted with the stereotypes of cruelty, monarchism, and drunkenness attributed by respondents to the perception of the Cossacks by foreigners.

A comparison of all the results obtained allows us to say that the culture of the Don Cossacks today is one-sided and is perceived by ordinary people accordingly. The assessments of the activity, the role of the Cossacks, and the personal attitude towards the Cossacks are formulaic and one-sided. All this allows us to talk about the existence of a stereotype of the Don Cossacks, the main conductor of which is the socio-cultural sphere.

The historical and cultural background of the development of the Cossacks and the consistent purposeful formation of certain social forces of the attitude towards them on the part of society allows us to suggest that even now the stereotype is formed not spontaneously, but according to the social order and under close supervision, if not control of the authorities. This is also evidenced by the close connection of the authorities with the activities of the Cossacks and with the representation of Cossack culture in the work of Cossack ensembles, sports and historical societies, which brings us to the topic of the populist context.

\section{Conclusions}

The analysis of diverse material using various methods leads us to the conclusion that the stereotyping of the Don Cossacks in modern culture is really happening. This process takes place against the background of the ambiguity of the issue of the ethnic and social identity of the Cossacks themselves, discussions about their status in society, the legitimacy of the privileges granted to them by the state. Accordingly, the research problem of stereotyping of the Don Cossacks at the moment has grounds that lie in different dimensions of the issue: historical, historical-cultural, socio-political, ethnographic, and communicative.

The one-sided and biased representation of the Cossacks in socio-cultural activities and tourist products provides conditions for the avalanche-like spread of stereotypical ideas about the Cossacks. In this regard, there are a number of issues that need to be studied.

\section{Reference}

1. Yip, Cultural Diversity \& Ethnic Minority Psychology, 22(1), 38-46, (2016), DOI: 10.1037/cdp0000046

2. K. Desmet, I. Ortuño-Ortín, R. Wacziarg, Culture, Ethnicity, and Diversity American Economic Review, 107(9), 2479-2513.(2017), DOI: https://doi.org/10.1257/aer.20150243.

3. P. F. Kotzur., S. Veit, A. Namyslo, M. Holthausen, British Journal of Social Psychology, 10(21) (2020), DOI: https://doi.org/10.1111/bjso.12375. 
4. S. Sena da, E. Jose, Horizonte-Revista de Estudos de Teologia e Ciencias da Religiao, 16, №1 (49), 136-165 (2018), DOI: 10.5752/P.2175-5841.2018v16n49p136-165.

5. N. Vlaskina, Folklore-Electronic Journal of Folklore, 66, 133-154 (2016), DOI: https://doi.org/10.7592/FEJF2016.66.vlaskina.

6. E. A. Murashova, Science Journal of VolSU. Linguistics, 16(2), 127-134 (2017), DOI: https://doi.org/10.15688/jvolsu2.2017.2.13.

7. A. Y. Peretyatko, Bylye Gody, 52(2), 605-614 (2019), DOI: 10.13187/bg.2019.2.605.

8. M. A. Ryblova, Science Journal of VolSU. History. Area Studies. International Relations, 24(4), 206-2014 (2019), DOI: https://doi.org/10.15688/jvolsu4.2019.4.17.

9. N. F. Bugay, Science Journal of VolSU. History. Area Studies. International Relations, 24(4), 148-163 (2019), DOI: https://doi.org/10.15688/jvolsu4.2019.4.13.

10. S. O. Dolgikh, Vestnik Tomskogo Gosudarstvennogo Universiteta Istoriya-Tomsk State University Journal of History, 54, 33-37 (2018), DOI: 10.17223/19988613/54/5.

11. G. O. Macievskiy, Science Journal of VolSU. History. Area Studies. International Relations, 24(4), 164-172 (2019), DOI: https://doi.org/10.15688/jvolsu4.2019.4.14.

12. N. G. Science Journal of VolSU. History. Area Studies. International Relations, 24(4), 191-201 (2019), DOI: https://doi.org/10.15688/jvolsu4.2019.4.16.

13. Y. I. Pertseva, Science Journal of VolSU. History. Area Studies. International Relations, 3(27), 93-104 (2014), DOI: http://dx.doi.org/10.15688/jvolsu4.2014.3.10.

14. A. Popov, Nationalities Papers-the Journal of Nationalism and Ethnicity, 46(1), 1-19 (2018), DOI: 10.1080/00905992.2017.1354363.

15. K. D. Vorozhko, Interactive science, 6, 82-84 (2016), DOI: 10.21661/r-112686.

16. L. N. Kazmina, V. S. Makarenko, V. V. Provotorina, T. N. Grigorenko, International Journal of Economics and Business Administration, 7, 510-520 (2019), doi: $10.35808 / \mathrm{ijeba} / 297$

17. L. N. Kazmina, V. V. Provotorina, Humanities and Socio-Economic Sciences, 5(96), 109-114 (2017)

18. V. V. Provotorina, L. N. Kazmina, A. S. Petrenko, G. E. Ekinil, E3S Web of Conferences, 175, 10002 (2020), doi: 10.1051/e3sconf/202017510002

19. L. N. Kazmina, V. S. Makarenko, V. V. Provotorina, E. M. Shevchenko, E3S Web of Conferences, 175, 10001 (2020), doi:10.1051/e3sconf/202017510001

20. V. V. Provotorina, L. N. Kazmina, A. S. Petrenko, V. S. Makarenko, Lecture Notes in Civil Engineering, 130, 20-32 (2020), https://doi.org/10.1007/978-981-33-6208-6_3

21. O. V. Rvacheva, Science Journal of VolSU. History. Area Studies. International Relations, 24(4), 173-190 (2019), DOI: https://doi.org/10.15688/jvolsu4.2019.4.15.

22. A. A.Volvenko, A. I. Mitrofanova, Shane Science Journal of VolSU. History. Area Studies. International Relations, 24, DOI: https://doi.org/10.15688/jvolsu4.2019.4.20.

23. N. Andrienko, S. Lukash, Journal of History Culture and Art Research, 7(1), 34-39 (2018), DOI: http://dx.doi.org/10.7596/taksad.v7i1.1448.

24. N. A. Mininkov., L. V. Mininkova, Bylye Gody, 54(4), 1761-1771 (2019), DOI: 10.13187/bg.2019.4.1761.

25. T. S. Rudichenko, Science Journal of VolSU. History. Area Studies. International Relations, 24(4), 215-223 (2019), DOI: https://doi.org/10.15688/jvolsu4.2019.4.18. 